\title{
Markiana nigripinnis (Perugia, 1891) as a putative member of the subfamily Stevardiinae (Characiformes: Characidae): spermatic evidence
}

\author{
Clarianna Martins Baicere-Silva ${ }^{1,2}$, Ricardo C. Benine ${ }^{2}$ and Irani Quagio-Grassiotto ${ }^{2}$
}

The genus Markiana was until recently recognized as incertae sedis in the family Characidae, even though alternative placements for this genus have been advanced since its original description. More recently, it was hypothesized that Markiana nigripinnis is part of a clade informally named the Astyanax clade, indicating the putative close relationship of Markiana with the genus Astyanax. Examination of sperm ultrastructure of representatives of Astyanax and M. nigripinnis shows no evidence for this hypothesized close relationship. Rather, the spermatozoa of M. nigripinnis share characters found in spermatozoa of the non-inseminating members of the subfamily Stevardiinae, such as an angle of nuclear rotation equal to $85^{\circ}$ resulting in a lateral position of the double nuclear fossa and flagellum. As with the non-inseminating Stevardiinae, sperm nuclei are also slightly elongate toward the flagellum, the proximal centriole is partially inside the nuclear fossa and anterior and oblique to the distal centriole, and the midpiece is short and strongly asymmetric. Additionally, M. nigripinnis shares with the other members of the Stevardiinae the presence of only four teeth in the inner row of the premaxillary and a short triangular ectopterygoid, which is never more than twice the length of the palatine.

O gênero Markiana até recentemente foi reconhecido como incertae sedis na família Characidae, apesar da localização alternativa para este gênero desde sua descrição original. Mais recentemente, surgiu a hipótese de que Markiana nigripinnis faz parte de um clado chamado informalmente de "Astyanax clade", indicando a suposta relação de Markiana com o gênero Astyanax. A análise da ultraestrutura dos espermatozoides de representantes do gênero Astyanax e M. nigripinnis não mostra nenhuma evidência de estreita relação. Pelo contrário, os espermatozóides de $M$. nigripinnis compartilham o padrão encontrado nos espermatozoides dos membros não-inseminadores da subfamília Stevardiinae, tais como, um ângulo de rotação nuclear igual a $85^{\circ}$ resultando em uma posição de lateral da fossa dupla nuclear e do flagelo. Assim como nos Stevardiinae não inseminadores, os núcleos dos espermatozoides também são ligeiramente alongados em direção ao flagelo, o centríolo proximal é anterior e oblíquo em relação ao centríolo distal e parcialmente inserido na fossa nuclear, e a peça intermediária é curta e fortemente assimétrica. Além disso, M. nigripinnis compartilha com os outros membros da Stevardiinae a presença de apenas quatro dentes na série interna da pré-maxila e um osso ectopterigoide curto e triangular, que nunca ultrapassa o dobro do comprimento do osso palatino.

Key words: Astyanax clade, Clade A, Spermiogenesis, Spermatozoa ultrastructure.

\section{Introduction}

The characid genus Markiana, was originally proposed by Eigenmann (1903), for the previously described Tetragonopterus nigripinnis Perugia, 1891, based mainly on the presence of premaxillary teeth set in two series, a complete lateral line, and crenate scales which are very regularly arranged and gradually decreasing in size from the lateral line to the ventral margin of the body. With only two known species, this genus has a disjunctive geographic

\footnotetext{
${ }^{1}$ Programa de Pós-Graduação em Biologia Geral e Aplicada, Instituto de Biociências, Universidade Estadual Paulista "Júlio de Mesquita Filho" (UNESP). Rubião Júnior, s/n, 18618-970 Botucatu, SP, Brazil. clariannamartins@yahoo.com.br

${ }^{2}$ Departamento de Morfologia, Instituto de Biociências, Universidade Estadual Paulista "Júlio de Mesquita Filho" (UNESP). Rubião Júnior, s/n, 18618-970 Botucatu, SP, Brazil.rbenine@hotmail.com (RCB), iraniqg@ibb.unesp.br (IQG)
} 
distribution, with M. nigripinnis (Fig. 1) confined to the rio da Prata basin plus the rio Mamoré, and M. geayi restricted to the río Orinoco system (Lima et al., 2003). The genus Markiana was until recently considered as incertae sedis in the Characidae, although various hypotheses as to the relationships of Markiana have been proposed since its description. Hypotheses based on exhaustive examination of characters using phylogenetic methodology that include the genus Markiana are largely limited to unpublished Ph.D. theses (Lucena, 1993; Benine, 2004; Moreira, 2007). Mirande (2010) provided what is to date the most comprehensive hypothesis about the phylogenetic interelationships within the Characidae. In this hypothesis, Markiana appeared closely related to Astyanax abramis, A. asuncionensis, and $A$. lineatus, and as part of a clade formed by all included species of Astyanax (except for A. latens and A. paris), Hyphessobrycon anisitsi and Psellogrammus kennedyi. Such a clade is weakly supported by the absence or presence of a single maxillary tooth and, for this reason, was only informally named the Astyanax clade.

Examination of the overall morphology of the spermatozoa of $M$. nigripinnis revealed similarities with the morphological pattern of the spermatozoa of the noninseminating members of Stevardiinae (Baicere-Silva et al., 2011). For an effective comparison, we accordingly describe the ultrastructural features of the spermatozoa of $M$. nigripinnis and present a discussion on its phylogenetic relationship.

\section{Material and Methods}

The material examined in this study is deposited in the Laboratório de Biologia e Genética de Peixes do
Departamento de Morfologia da Universidade Estadual Paulista "Júlio de Mesquita Filho" (LBP), Botucatu, and in the fish collection of the Museu de Zoologia da Universidade de São Paulo (MZUSP), São Paulo.

\section{Scanning Electron Microscopy (SEM)}

Cleared and stained (c\&s) specimens of Markiana nigripinnis were prepared following the method of Taylor \& van Dyke (1985). The premaxillary bones of the specimens were excised and prepared for observations in SEM. The material was washed in $70 \%$ alcohol, post-fixed in the dark for one hour in $0.5 \%$ osmium tetroxide in $0.1 \mathrm{M}$ Sorensen phosphate buffer, dehydrated in graded ethanol series to $100 \%$ ethanol, and critical point dried with liquid $\mathrm{CO}_{2}$. The bones were mounted on specimen stubs with colloidal silver and sputter-coated with approximately $20 \mathrm{~nm}$ of goldpalladium. Electron micrographs were obtained using a FEI Quanta 200 Scanning Electron Microscope.

\section{Transmission Electron Microscopy (TEM)}

Adult males of Markiana nigripinnis (LBP 4935) were anesthetized with $0.1 \%$ benzocaine and killed (according to approved institutional protocols) for the removal of testis. Gonad fragments from newly sacrificed fish were fixed overnight in $2 \%$ glutaraldehyde and $4 \%$ paraformaldehyde in $0.1 \mathrm{M}$ Sorensen phosphate buffer, $\mathrm{pH}$ 7.4. The material was post-fixed in the dark for two hours in $1 \%$ osmium tetroxide in the same buffer, stained in block with aqueous solution of 5\% uranyl acetate for two hours, dehydrated in acetone, embedded in araldite, and sectioned and stained with a saturated solution of uranyl acetate in $50 \%$ ethanol and lead citrate. Electron micrographs were obtained using a Phillips - CM 100 Transmission Electron Microscope.

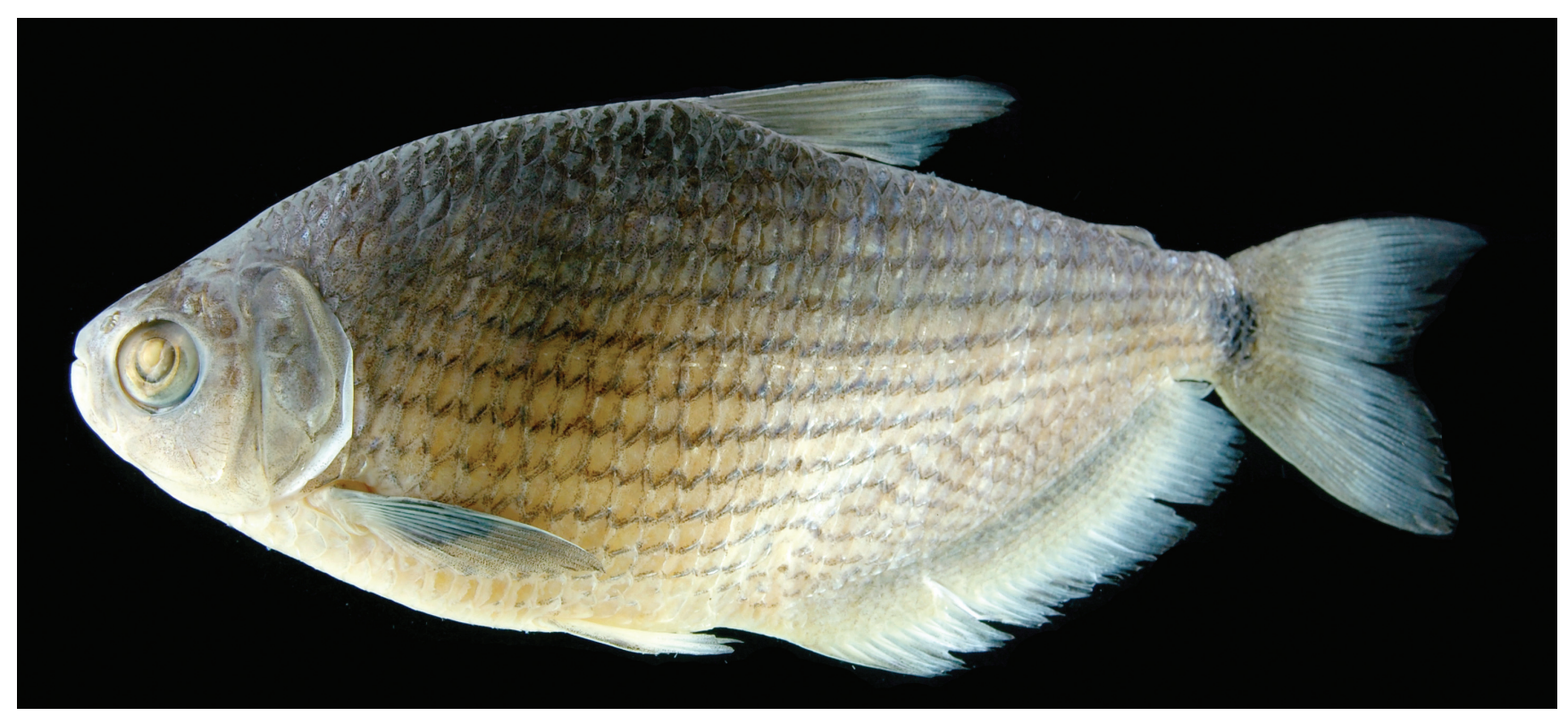

Fig. 1. Markiana nigripinnis, LBP 7586, 84.4 mm SL. Brasil, Mato Grosso, Barão de Melgaço, shore lake of rio Cuiabá. 

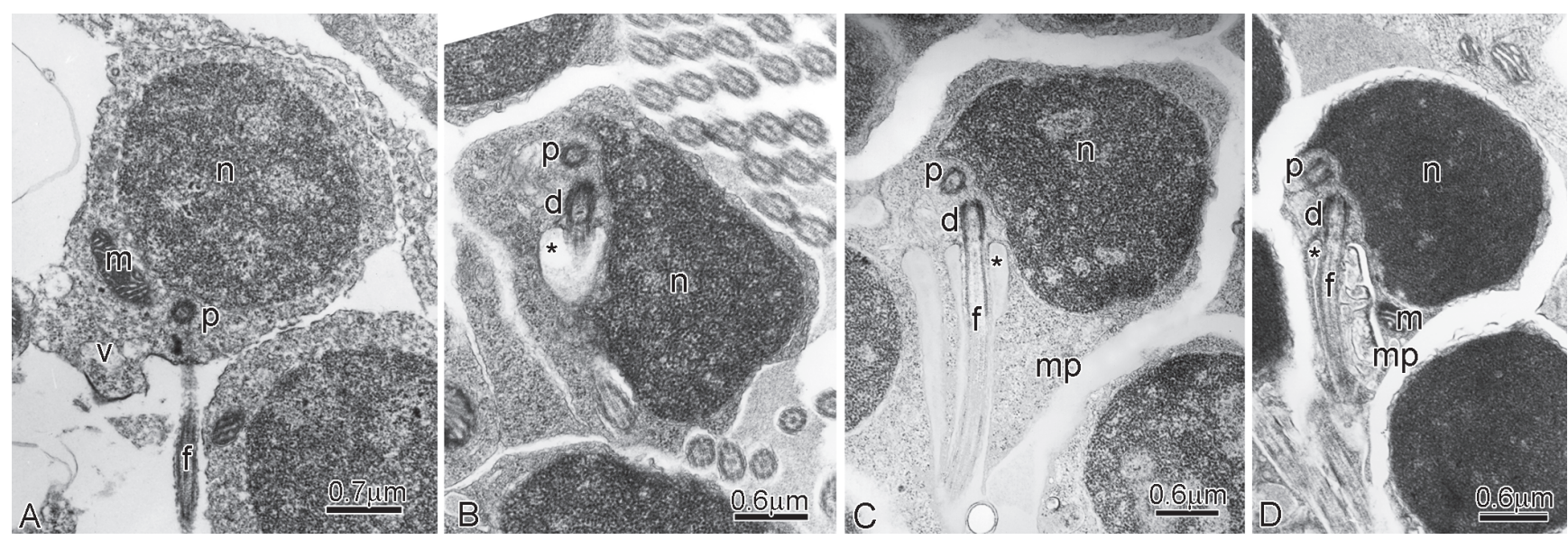

Fig. 2. Longitudinal sections of early to late spermatids of Markiana nigripinnis LBP 4935. A: Note that the centriolar complex is initially medial to the nucleus (n). B-D: The nuclear rotation toward the flagellar axis, the position of the proximal (p) and distal (d) centrioles, and the dislocation of the mitochondria $(\mathrm{m})$ and cytoplasm to the flagellar portion, forming the cytoplasmic canal $(*)$ and the midpiece (mp) of the spermatozoa.

\section{Results}

\section{Spermiogenesis (Fig. 2A-D)}

In the early spermatids of Markiana nigripinnis the cytoplasm symmetrically encircles the nucleus, which displays diffuse homogenous chromatin, and has a circular outline. The centriolar complex lies medial to the nucleus and is anchored to the plasma membrane (Fig. 2A). The proximal centriole is anteriorly and obliquely positioned relative to the distal centriole. The distal centriole is differentiated into the basal body and forms the flagellum (Fig. 2A). In the nucleus, chromatin starts to condense. A shallow double depression, the nuclear fossa, is formed in the nuclear outline at the level of the centriolar complex. The nucleus rotates approximately 85 degrees toward the flagellar axis (Fig. 2B). Consequently, the nuclear fossa, the centriolar complex and also the flagellum lie in a lateral position relative to base of the nucleus. Along with nuclear rotation, the cytoplasm is also shifted towards the flagellar axis giving rise to the midpiece (Fig. 2C). Since the distal centriole is anchored to the plasma membrane, when the cytoplasm shifts toward the flagellar axis it encircles the initial segment of the flagellum which forms the cytoplasmic canal. Most of the cytoplasm concentrates at the base of the nucleus, which is now strongly eccentric relative to the flagellar axis, making the midpiece asymmetric. The midpiece contains elongate mitochondria and vesicles. The progressive condensation of chromatin continues resulting in a highly condensed, granular pattern (Fig. 2D).

\section{Sperm (Fig. 3A-L)}

In the spermatozoa of Markiana nigripinnis, the nucleus is ovoid with maximum dimensions ranging up to $1.8 \mu \mathrm{m}$ in the longitudinal axis and $1.38 \mu \mathrm{m}$ in the transversal axis. The nucleus contains highly condensed granular chromatin and is surrounded by a narrow strip of cytoplasm without organelles (Fig. 3A). The nuclear outline has a shallow, lateral double nuclear fossa. Only the anterior portion of the proximal centriole is partially inside the nuclear fossa, and only the lateral section of the distal centriole is partially inside the nuclear fossa. Each of the centrioles is fastened to the nuclear envelope and to each other by stabilization fibrils. The distal centriole is also fastened to the plasma membrane. The proximal centriole is situated anteriorly and has an oblique angle relative to the distal centriole (Fig. $3 \mathrm{~A})$. The distal centriole differentiates into the basal body and gives rise to the flagellum. Because the nuclear fossa is laterally situated, the flagellum is also lateral (Fig. 3A-H). The midpiece (of approximately $1.5 \mu \mathrm{m}$ length) is strongly asymmetric, contains a cytoplasmic canal, an endomembrane system, and several elongate and ramified mitochondria (Fig. 3I-K). The mitochondria have a basolateral distribution and are mainly positioned next to the nucleus. The endomembrane system is composed on many vesicles with alveolar aspect. In cross section, vesicles are small, elongate and connected both with one another and to the plasma membrane (Fig. 3B). The flagellum contains a classic axoneme (9+2) and lacks lateral fins (Fig. 3L).

\section{Discussion}

According to Mirande (2010), Markiana nigripinnis shares with all examined species of Astyanax (except $A$. latens and A. paris), Hyphessobrycon anisitsi and Psellogrammus kennedyi, the non-exclusive synapomorphic condition of complete absence or presence of a single maxillary tooth, which is the only supportive character for the Astyanax clade. Notwithstanding the 


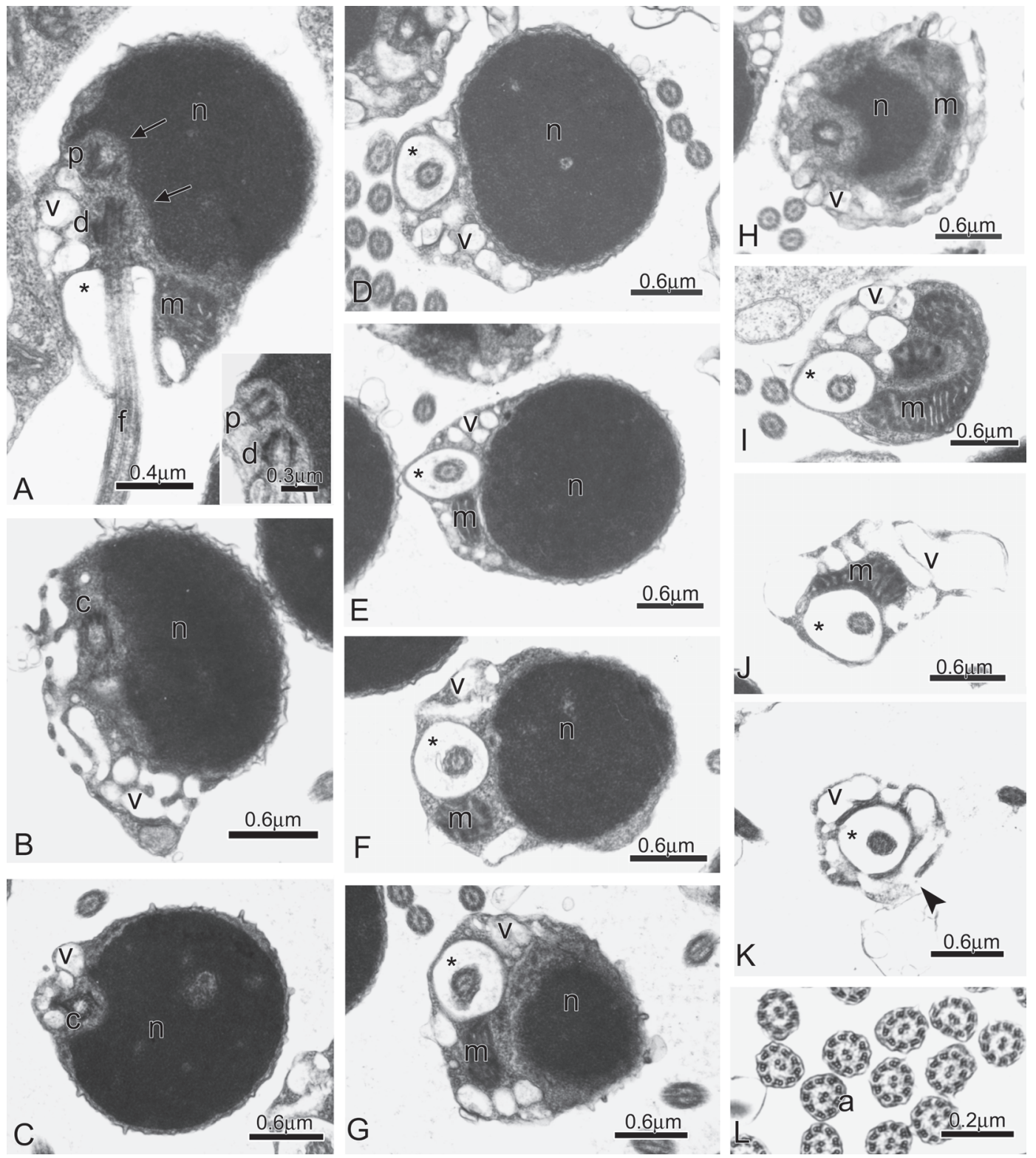

Fig. 3. Spermatozoa of Markiana nigripinnis LBP 4935. A: Longitudinal section of spermatozoon. Note the lateral position and pattern of chromatin condensation in the nucleus (n), the position of the double nuclear fossa (double arrows), the midpiece and the cytoplasmic canal $(*)$ containing the initial segment of the flagellum (f). A-Inset: Detail of the position, form and depth of the nuclear fossa, and the position of the proximal (p) and distal (d) centrioles to one another and to the nuclear fossa. B: Oblique section of spermatozoa. Note the alveolar aspect of the tubular vesicular system C-K: Cross sections at different levels of the stongly asymmetric midpiece, from the base of the nucleus (n) to the midpiece end. Note the lateral position of the centriole (c), cytoplasmic canal $(*)$ and of the flagellum (f), the distribution of a few elongate and ramified mitochondria (m) accumulated in larger side of the midpiece, tubular vesicular system (v). L: Cross section of the flagellum with the classic axoneme (a).

hypothesized close relationship between Markiana and species of Astyanax, the type of spermiogenesis and, consequently, the sperm morphology of M. nigripinnis, are markedly different from those observed not only in Astyanax fasciatus, but most species of Tetragonopterinae sensu Géry (1977, e.g. Bryconops affinis, Hemigrammus erythrozonus,
Hyphessobrycon eques, Moenkhausia sanctaefilomenae, Paracheirodon innesi, and Tetragonopterus argenteus according to the review of Burns et al., 2009).

Alternatively, Markiana nigripinnis shares the type of spermiogenesis observed in members of the Stevardiinae (sensu Mirande, 2009, 2010): Bryconacidnus ellisi, 


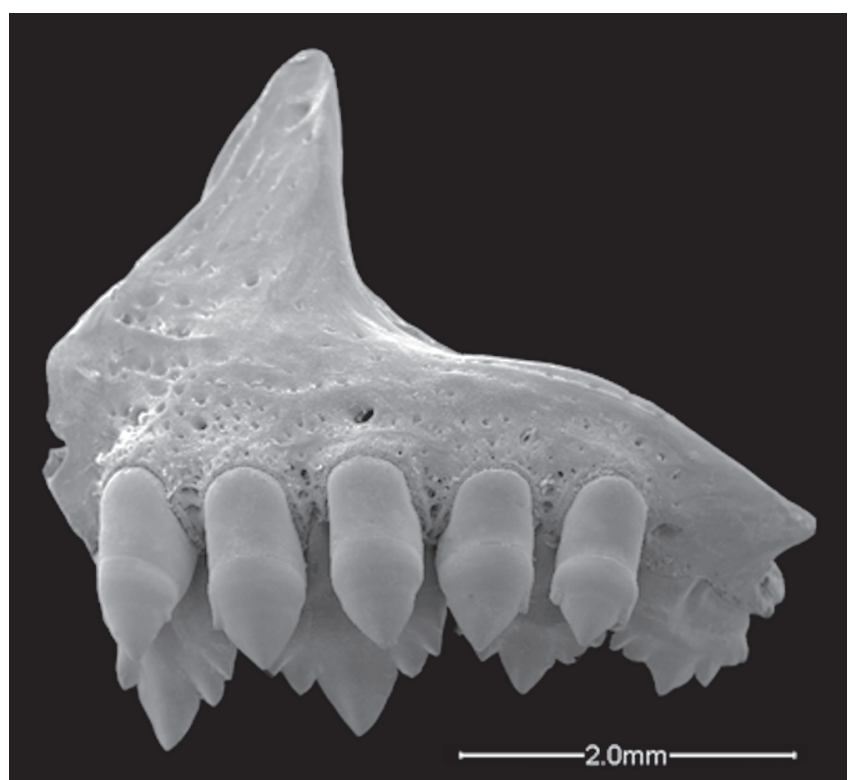

Fig. 4. Markiana nigripinnis, MZUSP 18850, premaxillary lateral view in SEM.

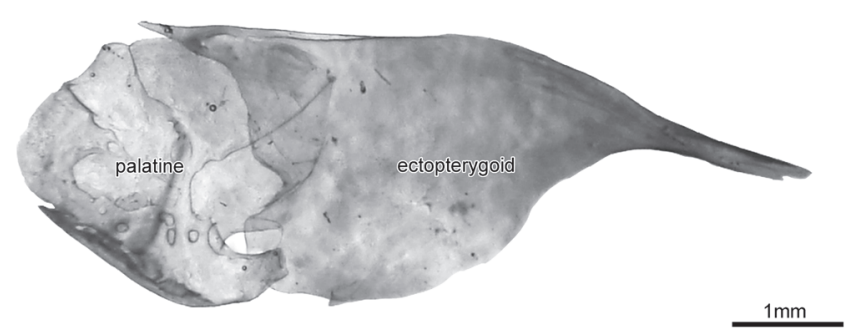

Fig. 5. Markiana nigripinnis MZUSP 18850, dorsal view of palatine and ectopterygoid bones.

Bryconamericus exodon, Boehlkea fredcochui, Ceratobranchia obtusirostris, Creagrutus meridionalis, Cyanocharax alburnus, Hemibrycon surinamensis, Knodus meridae, Odontostoechus lethostigmus, Piabina anhembi, Piabina argentea, and Rhinobrycon negrensis (BaicereSilva et al., 2011). Thus, M. nigripinnis also shares similar sperm morphology with these taxa, with the exception of features of mitochondria and vesicles. Nonetheless, the morphology of mitochondria and vesicles observed in $M$. nigripinnis is the same as that observed in Monotocheirodon (John R. Burns, pers. commun.) another member of the so-called Clade A (=Stevardinae, sensu Mirande, 2009, 2010) of Malabarba \& Weitzman (2003).

In terms of gross morphology, Markiana nigripinnis has only four teeth in the inner row of the premaxilla (Fig. 4), one of the synapomorphies for Clade A as proposed by Malabarba \& Weitzman (2003). It is worth noting that Markiana also has a short and triangular ectopterygoid, which never exceeds twice the length of the palatine (Fig. $5)$. That condition was previously reported as a synapomophy for a clade formed by Bryconamericus exodon, Knodus moenkhausii, Creagrutus varii, and Piabina argentea, all members of the subfamily Stevardiinae (Benine, 2004). In addition, Mirande (2010) discussed that although a close relationship between Bryconamericus scleroparius and Markiana nigripinnis is not supported in his hypothesis, these species also share the absence of an ossified rhinosphenoid, an overlap of the horizontal arm of the preopercle by the third infraorbital, and the presence of two uroneurals. It is noteworthy that these characters, along with the presence of only four teeth in the inner row of the premaxillar determined that these two species form a monophyletic clade in the analyses performed under selfweighted optimization both in Mirande (2009: fig. 4) and in several analyses performed by Mirande (2010).

Thus, the pattern of spermiogenesis, sperm morphology, and the discussed osteological features, all point to a close relationship between Markiana nigripinnis and members of the clade Stevardiinae.

Material examined. LBP 7586, 1, $87.8 \mathrm{~mm}$ SL, Brasil, Mato Grosso, Barão de Melgaço, shore lake of rio Cuiabá, 16¹1'39.5"S $55^{\circ} 48^{\prime} 25^{\prime \prime W}$. LBP 4935, 1, $68.4 \mathrm{~mm} \mathrm{SL}$, specimen from aquarium. MZUSP 18850, 1 c\&s, 82.2 mm SL, Brasil, Mato Grosso, Poconé, rio Cuiabá.

\section{Acknowledgements}

We would like to thank Luiz R. Malabarba (UFRGS) for the valuable suggestions and comments on various drafts of the manuscript and to the Electron Microscopy Laboratory/IBB-UNESP for use of their facilities. This research was supported by the Brazilian Agencies FAPESP (Fundação de Apoio à Pesquisa do Estado de São Paulo); CNPq (Conselho Nacional de Desenvolvimento Científico e Tecnológico); and CAPES/PROEX (Coordenação de Aperfeiçoamento de Pessoal de Nível Superior).

\section{Literature Cited}

Baicere-Silva, C. M., K. M. Ferreira, L. R. Malabarba, R. C. Benine \& I. Quagio-Grassiotto. 2011. Spermatic characteristics and sperm evolution on the subfamily Stevardiinae (Ostariophysi: Characiformes: Characidae). Neotropical Ichthyology, 9(2): 377-392.

Benine, R. C. 2004. Análise filogenética do gênero Moenkhausia Eigenmann, 1903 (Characiformes: Characidae) com uma revisão dos táxons do alto Rio Paraná. Unpublished Ph.D. Dissertation, Universidade Estadual Paulista, Botucatu, 317p.

Burns, J. R., I. Quagio-Grassiotto \& B. G. M. Jamieson. 2009. Ultrastructure of spermatozoa: Ostariophysi. Pp. 287-388. In: Jamieson, B. G. M. (Ed.). Reproductive biology and phylogeny of fish (Agnatha and Osteichthyes). Science Publishers, Enfield, 768p.

Eigenmann, C. H. 1903. New genera of South America fresh-water fishes, and new names for some old genera. Smithsonian Miscellaneous Collection, 45: 144-148. 
Géry, J. 1977. Characoids of the World. Neptune City, New Jersey, T. F. H. Publications, 672p.

Lima, F. C. T., L. R. Malabarba, P. A. Buckup, J. F. P, Silva, R. P. Vari, A. Harold, R. Benine, O. T. Oyakawa, C. S. Pavanelli, N. A. Menezes, C. A. S. Lucena, R. E. Reis, F. Langeani, L. Casatti, V. A. Bertaco, C. R. Moreira \& P. H. F. Lucinda. 2003. Genera incertae sedis in Characidae. Pp. 106-169. In: Reis, R. E., S. O. Kullander \& C. J. Ferraris, Jr. (Eds.). Check List of the Freshwater fishes of South and Central America. Porto Alegre, Edipucrs, 729p.

Lucena, C. A. S. 1993. Estudo filogenético da família Characidae com uma discussão dos grupos naturais propostos (Teleostei, Ostariophysi, Characiformes). Unpublished Ph.D. Dissertation, Universidade de São Paulo, 158p.

Malabarba, L. R. \& S. H. Weitzman. 2003. Description of a new genus with six species from southern Brazil, Uruguay and Argentina, with a discussion of a putative characid clade (Teleostei: Characiformes: Characidae). Comunicações do Museu de Ciências e Tecnologia da PUCRS, Série Zoologia, 16: 67-151.

Mirande, J. M. 2009. Weighted parsimony phylogeny of the family Characidae (Teleostei: Characiformes). Cladistics, 2: 574-613.

Mirande, J. M. 2010. Phylogeny of the family Characidae (Teleostei: Characiformes): from characters to taxonomy. Neotropical Ichthyology, 8(2): 385-568.

Moreira, C. L. R. 2007. Relações filogenéticas na ordem Characiformes (Teleostei: Ostariophysi). Unpublished Ph.D. Dissertation, Universidade de São Paulo, 468.

Taylor, W. R. \& G. C. van Dyke. 1985. Revised procedures for staining and clearing small fishes and other vertebrates for bone and cartilage. Cybium, 9: 107-119.

Accepted March 10, 2011

Published June 30, 2011 